\title{
Osmopriming improves seeds germination, growth, antioxidant responses and membrane stability during early stage of Moroccan alfalfa populations under water deficit
}

Mohammed Mouradi ${ }^{1}$, Abdelaziz Bouizgaren ${ }^{2}$, Mohamed Farissi ${ }^{3}$, Bouchra Makoudi ${ }^{1}$, Ablaa Kabbadj ${ }^{1}$, Anne-Aliēnor Very ${ }^{4}$, Hervē Sentenacc ${ }^{4}$, Ahmed Qaddoury ${ }^{1}$, and Cherki Ghoulam ${ }^{1 *}$

\section{ABSTRACT}

Osmopriming has a positive effect on the enhancement of seeds germination and seedlings growth, especially under stress conditions. This study investigated the effects of osmopriming with polyethylene glycol on alfalfa (Medicago sativa L.) seeds germination and seedlings antioxidant responses under drought stress. Seeds of five Moroccan alfalfa populations and an American Moapa variety were used to investigate the effect of osmopriming on seeds germination, seedlings growth, activities of antioxidant enzymes and membrane stability under two water deficit levels $(-0.45$ and $-0.75 \mathrm{MPa})$. Seeds were primed with polyethylene glycol $\left(\mathrm{PEG}_{6000}\right)(-0.6$ $\mathrm{MPa}$ ) for $24 \mathrm{~h}$ at $25^{\circ} \mathrm{C}$. The results showed that treated seeds presented higher germination rate and growth of $8 \mathrm{~d}$-old seedlings than untreated ones. Particularly, osmoprimed seeds of 'Adis-Tata' (Ad) and 'Riche' (Rc) populations presented the highest final germination percentages of $90.8 \%$ and $64 \%$, respectively, and seedlings shoot and root lengths under both levels of water deficit. The priming treatment enhanced the activity of peroxidase (PO) and catalase (CAT) and reduced the malonyldialdehyde (MDA) content and the electrolyte leakage under water deficit. Generally, the success of germination was positively correlated to PO and CAT activities and the degree of membrane stability in drought tolerant populations. However, the positive effect of the osmopriming technique on alfalfa drought tolerance remains limited in some tested populations, and severe water stress could inhibit germination and cause damages of alfalfa seedlings.

Key words: Catalase, electrolyte leakage, germination, malonyldialdehyde, Medicago sativa, osmopriming, peroxidase, water deficit.

${ }^{1}$ Université Cadi Ayyad, Faculté des Sciences et Techniques, B.P. 549, Guéliz, Marrakech, Maroc.

"Corresponding author (ghoulam@fstg-marrakech.ac.ma; c.ghoulam@uca.ma).

${ }^{2}$ Institut National de la Recherche Agronomique (INRA), Unité d'Amélioration Génétique des Plantes, B.P. 533, Guéliz, Marrakech, Maroc. ${ }^{3}$ Université Sultan Moulay Slimane, Faculté Polydsciplinaire, B. P. 592, Mghila, Beni Mellal, Maroc.

${ }^{4}$ Montpellier SupAgro, 2 place Pierre Viala, 34060 Montpellier Cedex 02, France.

Received: 11 November 2015.

Accepted: 28 March 2016.

doi:10.4067/S0718-58392016000300002

\section{INTRODUCTION}

Alfalfa (Medicago sativa $\mathrm{L}$.) is an essential cultivated forage legume in the world and Morocco. It has high protein content and can grow in arid and semi-arid regions because of its deep and straight root system. This system is able to absorb deep water (about $4 \mathrm{~m}$ and more) that can help to save plant's life in long-term drought (Hamidi and Safarnejad, 2010). Seed sowing is considered as a sensitive and critical stage to cold, drought and salinity in plant's life cycle (Ghassemi-Golezani et al., 2008). Seeds are massively exposed to several difficult environmental conditions such as drought and salinity, which may strongly influence seedlings establishment (Figueiredo e Albuquerque and Carvalho, 2003). Efficient seed germination, rapid and uniform seedlings emergence lead to successful culture establishment (Chen and Arora, 2011). The Moroccan alfalfa populations are considered as moderately tolerant to drought and salinity but there is a variant behavior within a lot of them (Bouizgaren, 2007; Latrach et al., 2014; Mouradi et al., 2016). In addition, many species and sub-species of Medicago also exhibit traits of agronomic interest, such as tolerance to grazing (rooting ability and regrowth) and disease (Bouizgaren, 2007).

Drought is one of the most important environmental factors limiting plants growth and productivity in the Mediterranean region, especially in North Africa. It strongly determines the natural distribution of plant species. Drought aggravates the impact of the other abiotic or biotic stresses to which plants are exposed. Exposure to this stress reduces germination rate and seedlings growth with significant variations from crop to crop (Hamidi and Safarnejad, 2010). An unavoidable consequence of drought exposure is the generation of reactive oxygen species (ROS). They can be extremely reactive with several cellular constituents such as proteins, lipids and nucleic acids (Cruz de Carvalho, 2008; Hasanuzzaman et al., 2013), which in turn result in negative effects on metabolism and cellular structures (Bartels and Sunkar, 2005; França et al., 2007).

Seed priming has been shown to improve germination and emergence of many species (Bradford, 1986). It may constitute a useful tool for overcoming drought problems, assuring a high and successful planted seed establishment. However, some alfalfa genotypes are more sensitive than others to this constraint (Bouizgaren et al., 2013; Mouradi et al., 2016). The priming technique could make these genotypes germinate as fast as the tolerant ones and may consequently be a substitute for genetic breeding improvements. Interestingly, priming repairs damage of aged seeds (Bailly et al., 1998; Butler et al., 2009) or those exposed to stresses (Sun et al., 2010; Yacoubi et al., 2013). It consists of 
soaking the seeds in an osmoticum of low water potential to control the amount of water supply to the seed. Priming with osmotica like mannitol, polyethylene glycol, sodium chloride, and water has been reported to be an economic, simple, and safe technique to rise the seed ability to osmotic adjustment and crop production under stressed environment (Amooaghaie, 2013).

In this context, the aim of the present work was to assess the effect of osmopriming technique on seed germination parameters of Moroccan alfalfa populations under water deficit (induced by $\mathrm{PEG}_{6000}$ ) and to study the activity of some enzymes related to the antioxidant defense and the degree of cell membrane's health of the young seedlings.

\section{MATERIALS AND METHODS}

\section{Plant material}

The seeds of the Moroccan alfalfa (Medicago sativa L.) populations 'Tafilalet' (Ta), 'Riche' (Rc), 'Adis-Tata' (Ad), 'Demnate 1' (Dm1), 'Demnate 2' (Dm2), and an American 'Moapa' (Mo) were provided by the National Institute of Agronomic Research (INRA), Marrakech. These populations are originated from, South-east, West oasis, and High Atlas Mountains of Morocco where they have been grown for many centuries and are still widely used by farmers in their traditional agro-ecosystems (Farissi et al., 2011).

\section{Seed priming and germination}

Seeds were surface sterilized with sodium hypochlorite $6 \%$ for $5 \mathrm{~min}$, and then rinsed three times with sterile distilled water and fully immersed $(1: 2, \mathrm{w} / \mathrm{v})$ in polyethylene glycol $20 \%(-0.6 \mathrm{MPa})\left(\mathrm{PEG}_{6000}\right)$ for $24 \mathrm{~h}$ at $25^{\circ} \mathrm{C}$ in dark aseptic conditions. The solutions of PEG were prepared by addition of corresponding PEG $_{6000}$ quantities to autoclaved distillated water (w/v) and filtered through $0.25 \mu \mathrm{m}$ sterile filter (Rahimi, 2013). After priming, seeds were rinsed three times with distilled water, dried for $48 \mathrm{~h}$ at room temperature (23 to $25^{\circ} \mathrm{C}$ ) and original moisture content as the unprimed seeds, and immediately used for germination tests.

Primed (-0.6 MPa) and unprimed (UPS) seeds of the six alfalfa genotypes were germinated for $8 \mathrm{~d}$ at $25{ }^{\circ} \mathrm{C}$ and total darkness in $9 \mathrm{~cm}$ Petri dishes containing two sterilized layers of filter paper moistened with $0,15,20$, 25 , and $30 \%$ of $\mathrm{PEG}_{6000}$, which correspond respectively to $0,-0.45,-0.6,-0.75$, and $-0.9 \mathrm{MPa}$ according to Michel and Kaufmann (1973). Three replicates of 40 seeds per treatment were executed. We considered seed germinated when 1 $\mathrm{mm}$ length radicle protruded through the seed coat. Final germination percentage (FGP), germination rate (GR), mean germination time (MGT), and time to $50 \%$ germination (T50) were considered to study the effect of osmopriming on the germination performance under drought. The number of germinated seeds was counted every day. The germination rate was calculated using formula $G R=n /(D n)$, where, $n$ is the number of germinated seeds, $D$ is the number of spent days from the beginning. Mean germination time (MGT) was calculated according to Moradi Dezfuli et al. (2008) using the formula $M G T=\Sigma D n / \Sigma n$, where $n$ represents the number of seeds germinated on day $D$, and $D$ is the number of days counted from the beginning of germination. The time to $50 \%$ germination (T50) was calculated according to the following formula of Coolbear et al. (1984) modified by Farooq et al. (2005):

$$
\mathrm{T} 50=\mathrm{t}_{\mathrm{i}}+\frac{\left\{(\mathrm{N} / 2)-\mathrm{n}_{\mathrm{i}}\right\}\left(\mathrm{t}_{\mathrm{i}}-\mathrm{t}_{\mathrm{j}}\right)}{\mathrm{n}_{\mathrm{i}}-\mathrm{n}_{\mathrm{j}}}
$$

where $N$ is the final number of germination and $n_{i}, n_{j}$ cumulative number of seeds germinated by adjacent counts at times $t_{i}$ and $t_{j}$ when $n_{i}<N / 2<n_{j}$.

The shoot and root lengths (SL and RL) were measured at the eighth day of sowing. The shoot to root ratio $(\mathrm{S} / \mathrm{R})$ was also calculated. Six seedlings were grouped as replicate with three replicates per genotype per treatment.

\section{Physiological and biochemical parameters} Electrolyte leakage and malonyldialdehyde contents. The electrolyte leakage was determined as described by Ghoulam et al. (2002). Fresh, germinated seedlings tissue (50 mg) were cut into pieces of $5 \mathrm{~mm}$ length and then placed in test tubes containing $10 \mathrm{~mL}$ of double-distilled water. The tubes were incubated in a water bath at $25^{\circ} \mathrm{C}$ for $24 \mathrm{~h}$ in a rotary shaker $\left(100 \mathrm{t} \mathrm{min}^{-1}\right)$ and the initial electrical conductivity of the medium (EC1) was measured using a conductivity meter (HI8820N, Hanna Instruments, Woonsocket, Rhode Island, USA). Then, samples were autoclaved at $121^{\circ} \mathrm{C}$ for $20 \mathrm{~min}$ to release all electrolytes and cooled to $25^{\circ} \mathrm{C}$, after which the final electrical conductivity (EC2) was measured. The electrolyte leakage (EL) was calculated using the formula: $E L=(E C 1 / E C 2) \times 100$. Six seedlings per treatment per genotypes were considered.

The malonyldialdehyde (MDA) content was determined after $8 \mathrm{~d}$ of germination according to Zhang and Kirham (1994). Samples of $50 \mathrm{mg}$ material from germinated alfalfa seedlings were ground in a mortar in $5 \mathrm{~mL}$ of $5 \%(\mathrm{w} / \mathrm{v})$ trichloroacetic acid and followed by centrifugation at 5000 $\times \mathrm{g}$ for $10 \mathrm{~min}$ at $4{ }^{\circ} \mathrm{C}$. The supernatant extract $(2 \mathrm{~mL})$ was collected and mixed with $2 \mathrm{~mL}$ thiobarbituric acid. Samples were boiled for $10 \mathrm{~min}$. After cooling down, absorbance of samples was measured spectrophotometrically at wavelengths of 532 at $600 \mathrm{~nm}$.

Antioxidant enzyme activities. The activities of peroxidase (PO) and catalase (CAT) were determined according to Gao (2000) and Zhang and Kirham (1994) respectively. A sample of $50 \mathrm{mg}$ fresh seedlings was ground in a mortar with pestle at $0{ }^{\circ} \mathrm{C}$ and $5 \mathrm{~mL}$ grinding media consisting of $50 \mathrm{mM}$ phosphate buffer solution (PBS, $\mathrm{pH}=7.8$ ) and $1 \%$ polyvinylpyrrolidone (PVP), followed by a $15 \mathrm{~min}$ centrifugation at $10000 \times \mathrm{g}$ and $4{ }^{\circ} \mathrm{C}$. The extract supernatant was collected and stored at $4{ }^{\circ} \mathrm{C}$ for enzyme assays. For PO, the oxidation of guaiacol was measured by the increase in absorbance at $470 \mathrm{~nm}$. For CAT, the decomposition of $\mathrm{H}_{2} \mathrm{O}_{2}$ was followed by the decline in absorbance at $240 \mathrm{~nm}$. The PO and CAT activities were expressed in enzyme units 
per milligram of fresh weight, where one enzyme unit was defined as a change of 0.01 absorbance $\mathrm{min}^{-1}$ caused by the enzyme aliquot.

\section{Statistical analysis}

The statistical analysis was performed using SPSS (10.0) software (IBM, Armonk, New York, USA). It concerned a three-way ANOVA III. Three replicates per population per treatment were executed. The means and calculated standard errors were reported. Tukey's test was applied for the comparison of means calculated.

\section{RESULTS}

\section{Germination of primed and unprimed seeds under water deficit}

Germination of alfalfa seeds was negatively affected ( $\mathrm{p}$ $<0.001$ ) by water deficit (Table 1). The final germination rate (FGP) in primed and unprimed alfalfa seeds was significantly reduced for both studied water deficit levels $(\mathrm{p}$ $<0.001)$. This parameter was significantly $(\mathrm{p}<0.001)$ higher in the majority of the primed alfalfa seeds at -0.45 and -0.75 $\mathrm{MPa}$ in comparison to the unprimed ones (Table 1). At the stress level of $-0.45 \mathrm{MPa}$, the primed seeds of Rc and $\mathrm{Ad}$ populations reached a FGP of $96.6 \%$ and $94.1 \%$ respectively, while the untreated seeds of these populations presented a FGP value of $94.1 \%$ under the similar conditions. The primed seeds of Ad, Rc, and Ta presented a FGP of 90.8\%, 64.1\%, and $43.3 \%$, respectively, while the mountain population
Dm2 presented $9.1 \%$ at the $-0.75 \mathrm{MPa}$ stress level (Table 1). According to Tukey's test, nonsignificant variations ( $p>$ $0.05)$ were detected between the two types of treatment for the populations Ad, Rc, and Dm1 at the stress level of -0.45 $\mathrm{MPa}$. The germination rate was also significantly $(\mathrm{p}<0.001)$ reduced under this constraint for the primed and unprimed seeds in all of the studied alfalfa populations. The primed seeds presented higher GR values $(\mathrm{p}<0.001)$ in comparison to the UPS (Table 1). At the stress level of $-0.45 \mathrm{MPa}$, primed seeds of Rc, Ad, and Ta populations reached a GR of $5.52 \pm$ $0.08,5.38 \pm 0.08$, and $5 \pm 0.14$, respectively. At this stress level, the osmopriming effect seems to be highly significant $(\mathrm{p}<0.001)$ for Dm2 and Mo. These genotypes presented GR values of $3.57 \pm 0.08$ and $1.19 \pm 0.16$ respectively. The primed seeds of the populations Ad and Rc reached GR of $5.2 \pm 0.047$ and $3.66 \pm 0.207$ in comparison to $0.52 \pm 0.047$ and $1.19 \pm 0.095$ presented by $\mathrm{Dm} 2$ and Mo respectively at $-0.75 \mathrm{MPa}$ treatment.

The mean germination time has been delayed significantly ( $\mathrm{p}<0.001)$ by drought for all of the studied alfalfa populations. According to ANOVA test, the seed priming and water deficit effects were nonsignificant. The treated seeds of Ad, Rc, and Ta populations presented the least MGT values $(0.15 \pm 0.047,0.24 \pm 0.022$, and $0.31 \pm 0.015$ respectively at $-0.75 \mathrm{MPa}$ water deficit level in comparison to untreated ones (Table 1).

The seed treatment by the $\mathrm{PEG}_{6000}$ significantly accelerated the T50 in the majority of the tested genotypes under -0.45 and $-0.75 \mathrm{MPa}(\mathrm{p}<0.01$, Table 1$)$ with different behaviors between the tested populations $(\mathrm{p}<0.001)$ according to

Table 1. Effect of polyethylene glycol (PEG $\left.{ }_{6000}\right)$ priming on germination parameters of alfalfa cultivars as compared to the unprimed controls under $0,-\mathbf{0 . 4 5}$, and $-\mathbf{0 . 7 5}$ MPa of PEG 6000 .

\begin{tabular}{|c|c|c|c|c|c|c|c|c|c|}
\hline \multirow[b]{2}{*}{ Cultivar } & \multirow{2}{*}{$\begin{array}{c}\text { Osmotic } \\
\text { potentials }\end{array}$} & \multicolumn{2}{|c|}{ FGP } & \multicolumn{2}{|c|}{ GR } & \multicolumn{2}{|c|}{ MGT } & \multicolumn{2}{|c|}{ T50 } \\
\hline & & Unprimed & Primed & Unprimed & Primed & Unprimed & Primed & Unprimed & Primed \\
\hline & & & $\%$ & & & & & $-\mathrm{d}$ & \\
\hline \multirow[t]{3}{*}{$\mathrm{Ta}$} & $0 \mathrm{MPa}$ & $99.1 \pm 0.83 \mathrm{ab}$ & $95.8 \pm 0.83 \mathrm{abcd}$ & $5.70 \pm 0.08 \mathrm{a}$ & $5.50 \pm 0.08 \mathrm{abc}$ & $0.12 \pm 0.001 \mathrm{~b}$ & $0.12 \pm 0.002 b$ & $0.81 \pm 0.01 \mathrm{klmn}$ & $0.64 \pm 0.05 n$ \\
\hline & $-0.45 \mathrm{MPa}$ & $80.0 \pm 1.44 \mathrm{~g}$ & $87.5 \pm 1.44 \mathrm{ef}$ & $4.60 \pm 0.14 \mathrm{~g}$ & $5.00 \pm 0.14 \mathrm{ef}$ & $0.17 \pm 0.004 b$ & $0.14 \pm 0.002 b$ & $1.52 \pm 0.03$ hijklmn & $0.69 \pm 0.06 \mathrm{mn}$ \\
\hline & $-0.75 \mathrm{MPa}$ & $26.6 \pm 0.83 n$ & $43.3 \pm 1.661$ & $1.50 \pm 0.08 n$ & $2.50 \pm 0.161$ & $0.75 \pm 0.02 b$ & $0.31 \pm 0.015 b$ & $2.65 \pm 0.07$ bcdef & $1.25 \pm 0.094 \mathrm{ijk} \mathrm{kmn}$ \\
\hline \multirow[t]{3}{*}{$\mathrm{Rc}$} & $0 \mathrm{MPa}$ & $96.6 \pm 0.83 \mathrm{abc}$ & $98.3 \pm 0.83 \mathrm{abc}$ & $5.52 \pm 0.08 \mathrm{abc}$ & $5.61 \pm 0.08 \mathrm{ab}$ & $0.12 \pm 0.001 \mathrm{~b}$ & $0.12 \pm 0.003 b$ & $0.76 \pm 0.04 \mathrm{klmn}$ & $0.59 \pm 0.03 n$ \\
\hline & $-0.45 \mathrm{MPa}$ & $94.1 \pm 0.83$ abcde & $96.6 \pm 0.83 \mathrm{abc}$ & $5.38 \pm 0.08$ abcde & $5.52 \pm 0.08 \mathrm{abc}$ & $0.16 \pm 0.002 b$ & $0.16 \pm 0.003 b$ & $1.76 \pm 0.06$ efghijk & $1.52 \pm 0.08$ ghijklmn \\
\hline & $-0.75 \mathrm{MPa}$ & $66.6 \pm 0.83 \mathrm{ij}$ & $64.1 \pm 3.63 \mathrm{j}$ & $3.80 \pm 0.08 \mathrm{ij}$ & $3.66 \pm 0.35 \mathrm{j}$ & $0.22 \pm 0.004 b$ & $0.24 \pm 0.022 b$ & $1.63 \pm 0.02$ ghijklm & $1.24 \pm 0.53 \mathrm{ijklmn}$ \\
\hline \multirow[t]{3}{*}{$\mathrm{Ad}$} & $0 \mathrm{MPa}$ & $100.0 \pm 0.01 \mathrm{a}$ & $98.3 \pm 0.83 \mathrm{abc}$ & $5.71 \pm 0.01 \mathrm{a}$ & $5.66 \pm 0.08 \mathrm{ab}$ & $0.12 \pm 0.001 b$ & $0.12 \pm 0.002 b$ & $0.60 \pm 0.01 \mathrm{n}$ & $0.57 \pm 0.01 \mathrm{n}$ \\
\hline & $-0.45 \mathrm{MPa}$ & $94.1 \pm 0.83$ abcde & $94.1 \pm 0.83$ abcde & $5.38 \pm 0.08$ abcde & $5.38 \pm 0.08$ abcde & $0.13 \pm 0.009 b$ & $0.13 \pm 0.001 \mathrm{~b}$ & $0.65 \pm 0.04 n$ & $0.78 \pm 0.051 \mathrm{mn}$ \\
\hline & $-0.75 \mathrm{MPa}$ & $89.1 \pm 0.83 \mathrm{def}$ & $90.8 \pm 0.83 \mathrm{cdef}$ & $5.09 \pm 0.08 \mathrm{def}$ & $5.20 \pm 0.08 \mathrm{cdef}$ & $0.16 \pm 0.001 b$ & $0.15 \pm 0.002 b$ & $2.36 \pm 0.55 \mathrm{cdefgh}$ & $1.20 \pm 0.04 \mathrm{ijk} \mathrm{kmn}$ \\
\hline \multirow[t]{3}{*}{ Dm1 } & $0 \mathrm{MPa}$ & $98.3 \pm 0.83 \mathrm{abc}$ & $96.6 \pm 0.83 \mathrm{abc}$ & $5.61 \pm 0.08 \mathrm{ab}$ & $5.52 \pm 0.08 \mathrm{abc}$ & $0.12 \pm 0.001 \mathrm{~b}$ & $0.12 \pm 0.002 b$ & $0.63 \pm 0.02 n$ & $0.59 \pm 0.02 \mathrm{n}$ \\
\hline & $-0.45 \mathrm{MPa}$ & $91.6 \pm 0.83 \mathrm{bcdef}$ & $88.3 \pm 0.83 \mathrm{ef}$ & $5.23 \pm 0.08 \mathrm{bcdef}$ & $5.04 \pm 0.08 \mathrm{ef}$ & $0.14 \pm 0.002 b$ & $0.15 \pm 0.003 b$ & $0.79 \pm 0.03 \mathrm{klmn}$ & $0.83 \pm 0.07 \mathrm{klmn}$ \\
\hline & $-0.75 \mathrm{MPa}$ & $37.5 \pm 1.44 \mathrm{~m}$ & $43.3 \pm 1.661$ & $2.14 \pm 0.14 \mathrm{~m}$ & $2.47 \pm 0.161$ & $0.45 \pm 0.007 b$ & $0.40 \pm 0.217 b$ & $2.10 \pm 0.43$ cdefghi & $2.50 \pm 0.04 \mathrm{bcdefg}$ \\
\hline \multirow[t]{3}{*}{ Dm2 } & $0 \mathrm{MPa}$ & $94.1 \pm 0.83 \mathrm{abcde}$ & $88.3 \pm 0.83 \mathrm{ef}$ & $5.38 \pm 0.08$ abcde & $5.04 \pm 0.08 \mathrm{ef}$ & $0.15 \pm 0.001 b$ & $0.14 \pm 0.002 b$ & $1.34 \pm 0.04 \mathrm{ijklmn}$ & $0.61 \pm 0.04 n$ \\
\hline & $-0.45 \mathrm{MPa}$ & $49.1 \pm 0.83 \mathrm{k}$ & $62.5 \pm 1.44 j$ & $2.80 \pm 0.08 \mathrm{k}$ & $3.57 \pm 0.08 \mathrm{j}$ & $0.33 \pm 0.002 b$ & $0.22 \pm 0.003 b$ & $2.14 \pm 0.03$ defghi & $0.75 \pm 0.07 \mathrm{lmn}$ \\
\hline & $-0.75 \mathrm{MPa}$ & $10.0 \pm 2.88 \mathrm{p}$ & $9.1 \pm 0.83 p$ & $0.57 \pm 0.28 p$ & $0.52 \pm 0.16 \mathrm{p}$ & $2.30 \pm 0.007 b$ & $1.76 \pm 0.021 \mathrm{~b}$ & $3.00 \pm 1 \mathrm{abcd}$ & $2.36 \pm 0.12 \mathrm{cdefgh}$ \\
\hline \multirow[t]{4}{*}{ Mo } & $0 \mathrm{MPa}$ & $91.6 \pm 0.83$ bcdef & $92.5 \pm 1.44$ bcdef & $5.23 \pm 0.08$ bcdef & $5.28 \pm 0.14$ bcdef & $0.15 \pm 0.002 b$ & $0.14 \pm 0.003 b$ & $1.46 \pm 0.79$ hijklmn & $0.70 \pm 0.05 \mathrm{mn}$ \\
\hline & $-0.45 \mathrm{MPa}$ & $74.1 \pm 1.66 \mathrm{~h}$ & $81.6 \pm 0.83 \mathrm{~g}$ & $4.23 \pm 0.16 \mathrm{~h}$ & $4.66 \pm 0.08 \mathrm{~g}$ & $0.21 \pm 0.003 b$ & $0.19 \pm 0.002 b$ & $1.69 \pm 0.48$ fghijkl & $0.78 \pm 0.18 \mathrm{klmn}$ \\
\hline & $-0.75 \mathrm{MPa}$ & $5.0 \pm 2.2 q$ & $20.8 \pm 1.660$ & $0.28 \pm 0.21 q$ & $1.19 \pm 0.160$ & $8.27 \pm 8 a$ & $0.83 \pm 0.134 b$ & $2.75 \pm 0.35 \mathrm{bcd}$ & $2.95 \pm 0.21 \mathrm{abcd}$ \\
\hline & & $\mathrm{dF}$ & F & $\mathrm{dF}$ & $\mathrm{F}$ & $\mathrm{dF}$ & F & $\mathrm{dF}$ & F \\
\hline \multicolumn{2}{|c|}{ Cultivars } & 5 & $826.62^{* * *}$ & 5 & $27.83^{* * * *}$ & 5 & $11.12^{* * * *}$ & 5 & $6.39^{* * *}$ \\
\hline \multicolumn{2}{|c|}{ Water deficit } & 2 & $5318.55^{* * *}$ & 2 & $6.93^{* *}$ & 2 & $2^{\mathrm{NS}}$ & 2 & $8.91^{* * *}$ \\
\hline \multicolumn{2}{|c|}{ Osmopriming } & 1 & $48.97^{* * *}$ & 1 & $0.73^{\mathrm{NS}}$ & 1 & $1^{\mathrm{NS}}$ & 1 & $8.98^{* *}$ \\
\hline \multicolumn{2}{|c|}{ Interactions } & 10 & $11.04^{* * *}$ & 10 & $1.02^{\mathrm{NS}}$ & 10 & $2.25^{*}$ & 10 & $2.76^{* *}$ \\
\hline
\end{tabular}

Means followed by standard errors and different letters are significantly different at $\mathrm{p}<0.05$.

${ }^{*},{ }^{* *},{ }^{* * *}$ Significant at the $0.05,0.01$, and 0.001 probability levels, respectively; NS: nonsignificant at 0.05 probability level. FGP: Final germination percentage, GR: germination rate, MGT: mean germination time, T50: time to 50\% germination. Ta: Tafilalet, Rc: Riche, Ad: Adis-Tata, Dm1: Demnate 1, Dm2: Demnate 2, Mo: Moapa. 
Tukey's test. The treated seeds of Ad, Rc, and Ta populations accelerated their germination under water deficit of -0.75 $\mathrm{MPa}$ to reach $1.2 \pm 0.047,1.24 \pm 0.532$, and $1.25 \pm 0.094$ $\mathrm{d}$ respectively. However, the values of $2.36 \pm 0.318,1.63 \pm$ 0.011 , and $2.65 \pm 0.042 \mathrm{~d}$ were respectively recorded for the untreated seeds of the same populations (Table 1).

According to the results analysis, shoot and root lengths of alfalfa seedlings were significantly $(\mathrm{p}<0.001)$ reduced by the high drought level in all of the studied populations. There were significant reductions of the shoot lengths and low decreases of the root lengths under this condition (Table 2), which lead to increase of the root to shoot ratio in the majority of the studied populations. Seeds treatment increased significantly ( $\mathrm{p}<0.001)$ the shoot and root lengths, especially in the two oasis populations $\mathrm{Rc}$, that reached $3.09 \pm 0.01$ and $3.23 \pm 0.3 \mathrm{~cm}$ respectively for shoot and root lengths, and Ad with $2.93 \pm 0.01$ and $3.73 \pm 0.23 \mathrm{~cm}$ respectively for both parameters under water deficit -0.75 MPa (Table 2).

\section{Effect on membrane permeability}

The effect of water deficit on membrane permeability was estimated according to the electrolyte leakage. Data indicated that the imposition of water deficit by the $\mathrm{PEG}_{6000}$ on alfalfa, at germination stage, increased significantly EL ( $p$ $<0.001$, Table 3 ). This physiological parameter decreased $(\mathrm{p}<0.001)$ in primed seeds under drought. The mountain populations presented the highest EL values under -0.75 $\mathrm{MPa}$ of $\mathrm{PEG}_{6000}$ in the untreated seedlings, while this damage was significantly less severe when primed with $-0.6 \mathrm{MPa}$ (Figure 1).
Table 3. Mean squares values from three-way ANOVA of water deficit, osmopriming, and alfalfa genotypes effects and their interactions for the considered parameters.

\begin{tabular}{lrrrrr}
\hline & df & PO & CAT & MDA & \multicolumn{1}{c}{ EL } \\
\hline Cultivars & 5 & $125.21^{* * *}$ & $408650.67^{* * *}$ & $0.164^{* * *}$ & $4139.69^{* * *}$ \\
Treatment & 2 & $2613.99^{* * *}$ & $2149811.37^{* * *}$ & $0.214^{* * *}$ & $21384.26^{* * *}$ \\
Priming & 2 & $492.06^{* * *}$ & $465340.89^{* *}$ & $2.615^{* * *}$ & $294.61^{* * *}$ \\
Cultivars $\times$ Treatment & 10 & $68.19^{* * *}$ & $138061.99^{* * *}$ & $0.041^{* * *}$ & $624.94^{* * *}$ \\
Cultivars $\times$ Priming & 10 & $44.75^{\text {*** }}$ & $35714.34^{* * *}$ & $0.014^{* * *}$ & $14.15^{* * *}$ \\
Treatment $\times$ Priming & 4 & $56.27^{* * *}$ & $48777.34^{* *}$ & $0.024^{* * *}$ & $4.47^{* * *}$ \\
Cultivars $\times$ Treatment & 20 & $10.37^{* * *}$ & $10744.61^{* * *}$ & $0.008^{* * *}$ & $2.45^{* * *}$ \\
$\times$ Priming & & & & & \\
Error & 108 & 1.16 & 277.12 & 6.25 & 2.25 \\
\hline
\end{tabular}

*,**,*** Significant at the $0.05,0.01$, and 0.001 probability levels, respectively; NS: nonsignificant at 0.05 probability level.

df: Degree of freedom, PO: peroxidase, CAT: catalase, MDA: malonyldialdehyde, EL: electrolyte leakage.

\section{Malondialdehyde contents}

Because of water deficit, MDA content in alfalfa seedlings significantly increased $(\mathrm{p}<0.001$, Table 3$)$. The accumulation of MDA was significantly progressive with the increase of stress level and remarkably decreased when priming with -0.6 $\mathrm{MPa}$ of $\mathrm{PEG}_{6000}$ (Figure 2). Among all of the populations, the oasis ones showed the least MDA accumulation under the two stress levels, especially in primed seeds. The Ad, Ta, and Rc populations accumulated $0.224,0.274$, and $0.334 \mathrm{mg} \mathrm{g}^{-1}$ FW under $-0.75 \mathrm{MPa}$ of $\mathrm{PEG}_{6000}$ respectively.

\section{Changes in peroxidase and catalase activities in alfalfa seedlings}

Results showed that PO and CAT enzymatic activities were significantly $(\mathrm{p}<0.001)$ increased under water deficit of -0.45 and $-0.75 \mathrm{MPa}$ in seedlings of primed and unprimed

Table 2. Effects of polyethylene glycol $\left(\mathrm{PEG}_{6000}\right)$ priming on some growth parameters of alfalfa cultivars as compared to the unprimed controls under $0,-\mathbf{- 0 . 4 5}$, and -0.75 MPa of PEG 6000 .

\begin{tabular}{|c|c|c|c|c|c|c|c|}
\hline \multirow[b]{2}{*}{ Cultivar } & \multirow{2}{*}{$\begin{array}{c}\text { Osmotic } \\
\text { potentials } \\
(\mathrm{MPa})\end{array}$} & \multicolumn{2}{|c|}{ Shoot length } & \multicolumn{2}{|c|}{ Root length } & \multicolumn{2}{|c|}{ Shoot to root ratio } \\
\hline & & Unprimed & Primed & Unprimed & Primed & Unprimed & Primed \\
\hline \multirow[t]{3}{*}{$\mathrm{Ta}$} & 0 & $5.03 \pm 0.02 \mathrm{~cd}$ & $5.13 \pm 0.01 b c$ & $4.80 \pm 0.1 \mathrm{cde}$ & $5.25 \pm 0.18 \mathrm{ab}$ & 0.95fghijk & 1.02cdefghi \\
\hline & -0.45 & $3.43 \pm 0.2 \mathrm{i}$ & $3.97 \pm 0.01 \mathrm{~g}$ & $3.72 \pm 0.02 \mathrm{kl}$ & $4.44 \pm 0.07$ efgh & 1.08 cdefgh & $1.12 \mathrm{cdefg}$ \\
\hline & -0.75 & $1.96 \pm 0.11 q$ & $1.44 \pm 0.01 \mathrm{st}$ & $1.63 \pm 0.05 t$ & $1.95 \pm 0.01 \mathrm{~s}$ & $0.83 \mathrm{jk}$ & $1.35 \mathrm{~b}$ \\
\hline \multirow[t]{3}{*}{$\mathrm{Rc}$} & 0 & $5.10 \pm 0.1 b c$ & $5.43 \pm 0.14 a$ & $5.04 \pm 0.18 \mathrm{bcd}$ & $4.92 \pm 0.01 \mathrm{bcd}$ & 0.99defghij & $0.90 \mathrm{ijk}$ \\
\hline & -0.45 & $3.63 \pm 0.25 h$ & $4.06 \pm 0.01 \mathrm{~g}$ & $3.83 \pm 0.05$ & $4.46 \pm 0.04 \mathrm{efgh}$ & $1.05 \mathrm{cdefghi}$ & 1.1cdefg \\
\hline & -0.75 & $2.42 \pm 0.01 \mathrm{~m}$ & $3.09 \pm 0.01 \mathrm{k}$ & $2.63 \pm 0.05 p q$ & $3.23 \pm 0.3 \mathrm{mn}$ & $1.08 \mathrm{cdefgh}$ & 1.04cdefghi \\
\hline \multirow[t]{3}{*}{ Ad } & 0 & $5.17 \pm 0.02 b c$ & $5.29 \pm 0.01 \mathrm{ab}$ & $5.04 \pm 0.06 \mathrm{bcd}$ & $5.53 \pm 0.36 a$ & 0.98defghij & 1.04cdefghi \\
\hline & -0.45 & $3.26 \pm 0.08 j$ & $3.70 \pm 0.01 \mathrm{~h}$ & $3.73 \pm 0.2 \mathrm{kl}$ & $4.42 \pm 0.01 \mathrm{fghi}$ & $1.14 \mathrm{cdef}$ & $1.19 \mathrm{c}$ \\
\hline & -0.75 & $2.35 \pm 0.01 \mathrm{mn}$ & $2.93 \pm 0.011$ & $2.77 \pm 0.08 \mathrm{op}$ & $3.37 \pm 0.231 \mathrm{~m}$ & $1.18 \mathrm{c}$ & $1.15 \mathrm{cde}$ \\
\hline \multirow[t]{3}{*}{ Dm1 } & 0 & $4.39 \pm 0.01 \mathrm{ef}$ & $4.46 \pm 0.12 \mathrm{e}$ & $4.28 \pm 0.01 \mathrm{ghij}$ & $4.32 \pm 0.03$ ghij & 0.97efghijk & 0.97efghijk \\
\hline & -0.45 & $2.15 \pm 0.05 \mathrm{nopq}$ & $2.32 \pm 0.01 \mathrm{mn}$ & $2.40 \pm 0.03 \mathrm{qr}$ & $2.69 \pm 0.02 \mathrm{pq}$ & 1.11cdefg & $1.15 \mathrm{cde}$ \\
\hline & -0.75 & $1.17 \pm 0.03 \mathrm{u}$ & $1.28 \pm 0.01 \mathrm{tu}$ & $2.06 \pm 0.01 \mathrm{rs}$ & $2.21 \pm 0.04 \mathrm{rs}$ & $1.75 \mathrm{a}$ & $1.72 \mathrm{a}$ \\
\hline \multirow[t]{3}{*}{$\mathrm{Dm} 2$} & 0 & $4.27 \pm 0.06 f$ & $4.39 \pm 0.01$ & $4.78 \pm 0.01 \mathrm{def}$ & $5.02 \pm 0.01 \mathrm{bcd}$ & $1.12 \mathrm{cdefg}$ & $1.14 \mathrm{cdef}$ \\
\hline & -0.45 & $2.01 \pm 0.01 \mathrm{pq}$ & $2.21 \pm 0.01 \mathrm{nop}$ & $2.06 \pm 0.02 \mathrm{rs}$ & $3.09 \pm 0.01 \mathrm{mno}$ & 1.02cdefghi & $1.39 \mathrm{~b}$ \\
\hline & -0.75 & $1.31 \pm 0.01 \mathrm{tu}$ & $1.55 \pm 0.01 \mathrm{~s}$ & $1.16 \pm 0.1 \mathrm{u}$ & $3.09 \pm 0.02 \mathrm{mno}$ & $0.88 \mathrm{ijk}$ & 0.92hijk \\
\hline \multirow[t]{3}{*}{ Mo } & 0 & $4.87 \pm 0.04 d$ & $4.99 \pm 0.01 \mathrm{~cd}$ & $4.05 \pm 0.01 \mathrm{ijk}$ & $4.92 \pm 0.02 b c d$ & $0.83 \mathrm{jk}$ & 0.99defghij \\
\hline & -0.45 & $2.09 \pm 0.08 \mathrm{opq}$ & $2.35 \pm 0.02 \mathrm{mn}$ & $2.35 \pm 0.12 \mathrm{qr}$ & $2.71 \pm 0.05 p q$ & $1.12 \mathrm{cdefg}$ & $1.15 \mathrm{cde}$ \\
\hline & -0.75 & $1.50 \pm 0.11 \mathrm{~s}$ & $1.81 \pm 0.01 \mathrm{r}$ & $1.23 \pm 0.05 \mathrm{u}$ & $1.46 \pm 0.03 \mathrm{tu}$ & $0.82 \mathrm{jk}$ & $0.8 \mathrm{k}$ \\
\hline Cultivars & & 5 & $1081.68^{* * * *}$ & 5 & $488.01^{* * * *}$ & 5 & $105.11^{* * * *}$ \\
\hline Water deficit & & 2 & $14431.45^{\text {**** }}$ & 2 & $5206.44^{* * * *}$ & 2 & $116.54^{* * *}$ \\
\hline Osmopriming & & 1 & $271.31^{* * *}$ & 1 & $399.9^{* * *}$ & 1 & $60.9^{* * *}$ \\
\hline Interactions & & 10 & $17.27^{* * *}$ & 10 & $9.53^{* * *}$ & 10 & $18.14^{* * *}$ \\
\hline
\end{tabular}

Means followed by standard errors and different letters are significantly different at $\mathrm{p}<0.05$.

${ }^{*},{ }^{* *},{ }^{* * *}$ Significant at the $0.05,0.01$, and 0.001 probability levels, respectively; NS: nonsignificant at 0.05 probability level.

Ta: Tafilalet, Rc: Riche, Ad: Adis-Tata, Dm1: Demnate 1, Dm2: Demnate 2, Mo: Moapa. 
Figure 1. Effect of osmopriming on electrolyte leakage (EL) of alfalfa cultivars as compared to the unprimed controls under different stress levels. Bars represent SE.

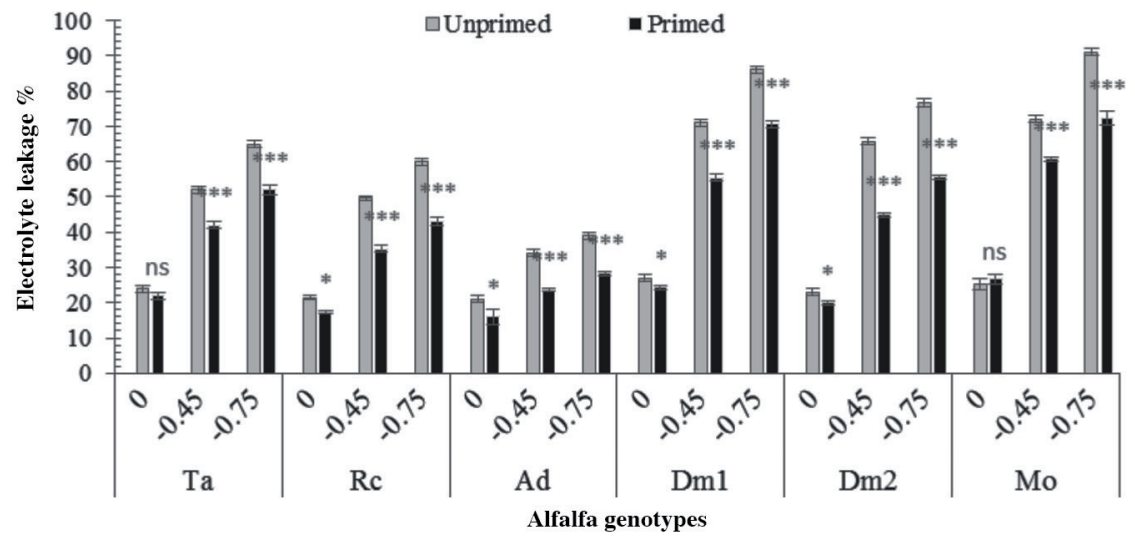

${ }^{*},{ }^{* *},{ }^{* * *}$ Significant at the $0.05,0.01$, and 0.001 probability levels, respectively; ns: nonsignificant at 0.05 probability level.

Ta: Tafilalet, Rc: Riche, Ad: Adis-Tata, Dm1: Demnate 1, Dm2: Demnate 2, Mo: Moapa.

Figure 2. Effect of osmopriming on malonyldialdehyde (MDA) of alfalfa cultivars as compared to the unprimed controls under different stress levels. Bars represent SE.

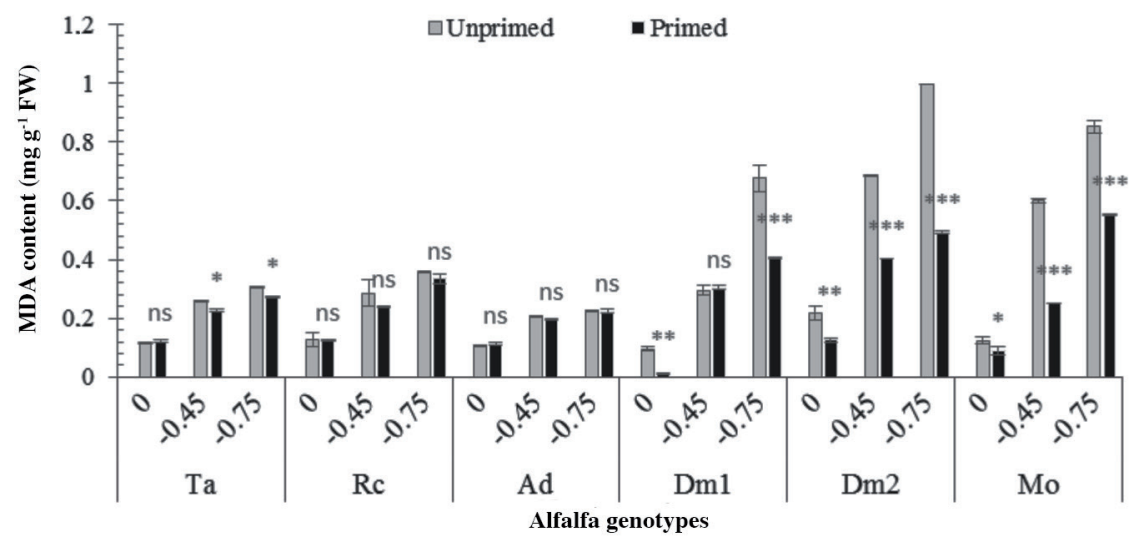

${ }^{*},{ }^{* *},{ }^{* * *}$ Significant at the $0.05,0.01$, and 0.001 probability levels, respectively; ns: Nonsignificant at 0.05 probability level. Ta: Tafilalet, Rc: Riche, Ad: Adis-Tata, Dm1: Demnate 1, Dm2: Demnate 2, Mo: Moapa.

seeds in the studied populations (Figures 3 and 4). Also, significant $(\mathrm{p}<0.001)$ differences between the alfalfa populations were noticed (Table 3). Seedlings of both primed and unprimed seeds of the oasis populations showed an important $\mathrm{PO}$ and CAT activities under water deficit level of $-0.75 \mathrm{MPa}$ in comparison to the mountain ones and the American 'Moapa' variety. The seedlings of unprimed seeds in $\mathrm{Ad}, \mathrm{Ta}$, and $\mathrm{Rc}$ populations presented a maximum $\mathrm{PO}$ and CAT activities of $18.73 \pm 0.60,16.54 \pm 0.66$, and $20.82 \pm$ $0.68 \mathrm{IU} \mathrm{min} \mathrm{m}^{-1} \mathrm{~g}^{-1} \mathrm{FW}$ respectively. Under water deficit of $-0.75 \mathrm{MPa}$, these activities were $347.62 \pm 1.9,355.34 \pm$ 22.68 , and $326.07 \pm 4.46 \mathrm{IU} \mathrm{min} \mathrm{m}^{-1} \mathrm{FW}$ for the mentioned populations respectively (Figures 1 and 2). The seedlings of primed seeds with $-0.6 \mathrm{MPa}$ of $\mathrm{PEG}_{6000}$ presented high PO and CAT activities compared to those of the untreated ones. The oasis populations presented the highest values under water deficit (-0.75 MPa). The PO and CAT activities, in Ad population, reached $27.94 \pm 1.07$ and $424.5 \pm 1.89 \mathrm{IU}$ $\mathrm{min}^{-1} \mathrm{~g}^{-1} \mathrm{FW}$ respectively (Figures 3 and 4 ).

\section{DISCUSSION}

In this study, the main aim was to assess the ability of PEG priming to induce drought tolerance and seed germination performance of alfalfa originated from Moroccan oasis and mountain. Osmopriming consists of soaking seeds before sowing, in the PEG solution to initiate the membrane repairing systems and metabolic preparation for germination via controlling the water absorption rate of seeds (Jisha et al., 2013). This technique is frequently used in some countries for vegetables and flower crops (Halmer, 2004). Therefore, the germination performance could be previously enhanced face to unfavorable conditions such as severe water deficit, which constitute the main environmental factor that negatively affects crop productivity and persistence. According to our results, we confirmed that osmopriming with PEG $_{6000}$ enhanced germination potential and increased its speed in all of the studied alfalfa populations with significant differences among them. Generally, alfalfa seeds after 
Figure 3. Effect of osmopriming on peroxidase (PO) of alfalfa genotypes as compared to the unprimed controls under different stress levels. Bars represent SE.

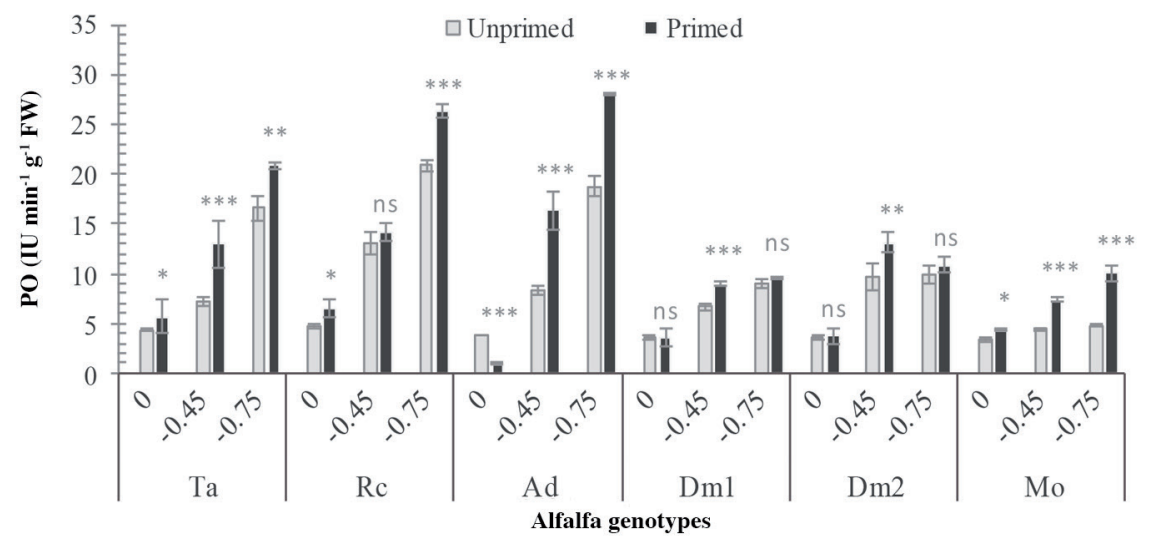

$*{ }^{* *}, * * *$ Significant at the $0.05,0.01$, and 0.001 probability levels, respectively; ns: Nonsignificant at 0.05 probability level. Ta: Tafilalet, Rc: Riche, Ad: Adis-Tata, Dm1: Demnate 1, Dm2: Demnate 2, Mo: Moapa.

Figure 4. Effect of osmopriming on catalase (CAT) of alfalfa genotypes as compared to the unprimed controls under different stress levels. Bars represent SE.

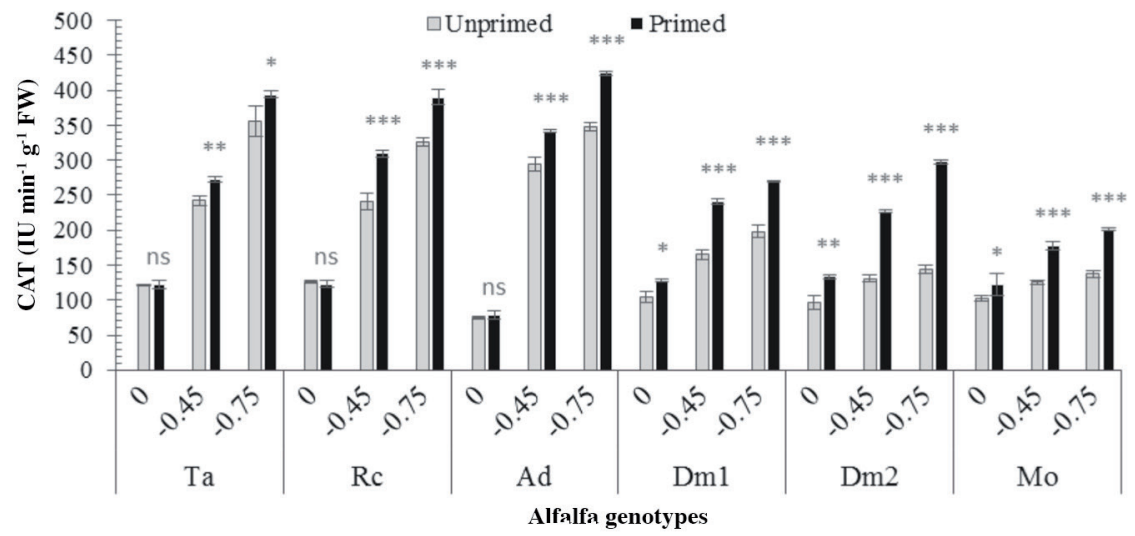

${ }^{*},{ }^{* *},{ }^{* * *}$ Significant at the $0.05,0.01$, and 0.001 probability levels, respectively; ns: Nonsignificant at 0.05 probability level. Ta: Tafilalet, Rc: Riche, Ad: Adis-Tata, Dm1: Demnate 1, Dm2: Demnate 2, Mo: Moapa.

priming showed an improvement of germination ability and seedlings growth in comparison to those germinated without priming treatment under water deficit. However, the positive effect of priming treatment on the alfalfa drought tolerance was evident, and there was a significant variation among the tested genotypes. For example, after priming, the 'Adis-Tata' oasis population germinated under -0.9 MPa of PEG (data not shown) while this stress level inhibited seed germination for the other genotypes. The beneficial effects of seed priming in improving germination rate under some abiotic stresses have been reported on some alfalfa genotypes (Amooaghaie, 2013) and other legumes, such as faba bean (Harb, 1992), soybean (Sadeghi et al., 2011) and other crops; cumin and rice (Rahimi, 2013). At the molecular level, the priming may be strongly related to drought tolerance. Indeed, Conrath (2011) proposed that priming involves the accumulation of inactive cellular kinases cascades and chromatin structure modification and thus amplifying the activation of stress defense genes.

Generally, steady decreases ( $\mathrm{p}<0.001$; Table 3) of seed germination have been noted for all of the tested $M$. sativa populations upon the exposure to increasing PEG concentrations (Table 1). Hamidi and Safarnejad (2010) reported that drought stress induced by PEG $_{6000}$ decreased germination rate in alfalfa cultivars and this reduction might due to the slower decomposition or transmission of the endosperm materials into plantlets. Large variation among the studied populations was observed in terms of this parameter. Indeed, the oasis populations showed interesting values in terms of germination percentages, germination rate, MGT and T50 even under stressful conditions, especially when primed with -0.6 MPa PEG. Our results indicate that the priming of alfalfa seeds with $-0.6 \mathrm{MPa}$ of $\mathrm{PEG}_{6000}$ at $25{ }^{\circ} \mathrm{C}$ for $24 \mathrm{~h}$ enhanced drought tolerance at germination stage. Similar findings were reported by Rahimi (2013) and Sun et al. (2010) for cumin and rice.

Tolerance to drought is strongly correlated to maintaining high antioxidant enzymes activities to avoid oxidative stress damages caused by ROS over produced in the tissues in case of drought. Generally, tolerant genotypes have the ability to protect themselves, by enhancing the synthesis of antioxidant enzymes and low antioxidant molecules (Foyer and Noctor, 2005). These compounds together could neutralize the toxic effect of peroxide, superoxide and hydroxyl radicals in the tissues (Mittler, 2002; Wang et al., 2009). In this study, we 
observed significant increases of PO and CAT activities under drought in germinated seeds in all of the tested alfalfa genotypes. These increases were relatively different among the tested cultivars. Therefore, the CAT activity was significantly correlated $\left(r=0.161^{*}\right)$ to the germination performance under water deficit, this could be explained by the inducing of CAT enzyme, which plays a key role in the protection and repairing systems under drought, especially when priming seeds by PEG (Kibinza et al., 2011).

To investigate the effect of osmopriming on membrane stability under drought, we measured MDA content and the degree of membrane permeability in these seedlings because of the oxidative stress engendered by the ROSs. Results showed that priming improved membrane protection in the majority of the alfalfa seedlings under severe drought stress $(-0.75$ MPa PEG), especially those primed with -0.6 MPa PEG 6000 . Similar results were reported by Chen and Arora (2011) after $48 \mathrm{~h}$ in spinach seeds, and Amooaghaie (2013) in alfalfa under salt stress. Under similar conditions, 'Adis-Tata' population showed the greatest membrane health status in comparison to other genotypes. It presented the least MDA content and electrolyte leakage among the tested populations. This might be due to the important level of antioxidant enzymes such as PO and CAT (Mittler, 2002; Wang et al., 2009).

Furthermore, significant negative correlations were detected between FGP and MDA contents and EL indicating the relationship between germination performance of primed seeds under drought and membrane stability in the studied seedlings. The low accumulation of MDA in the tolerant cultivars could be explained by decomposition of the ROS via increasing CAT and PO activities and suggests a high protection observed in some Medicago cultivars from oxidative damage (Wang et al., 2009; Sharma et al., 2012).

\section{CONCLUSIONS}

Our results showed that drought causes germination and growth reduction, membrane instability, and the induction of antioxidant enzymes. The present results suggested that the osmopriming technique enhanced drought tolerance of the studied alfalfa populations by improving seed germination performance, seedling growth and antioxidant defense system under the severe water deficit. The strongest inhibition occurred at the highest polyethylene glycol concentration (-0.9 $\mathrm{MPa})$ and a significant difference was evident between the studied genotypes. The treated seeds of 'Adis-Tata' and 'Riche' populations showed higher level of drought tolerance in comparison to others. At the early seedling stage, the tolerance of 'Adis-Tata' and 'Riche' to water deficit was associated with high antioxidant defense, low accumulation of malonyldialdehyde and low membrane electrolyte leakage.

\section{REFERENCES}

Amooaghaie, R. 2013. The effect of hydro and osmopriming on alfalfa seed germination and antioxidant defenses under salt stress. African Journal of Biotechnology 10(33):6269-6275. doi:10.5897/AJB10.2448.

Bailly, C., A. Benamar, F. Corbineau, and D. Come. 1998. Free radical scavenging as affected by accelerated ageing and subsequent priming in sunflower seeds. Physiologia Plantarum 104(4):646-652. doi:10.1034/j.1399-3054.1998.1040418.x.

Bartels, D., and R. Sunkar. 2005. Drought and salt tolerance in plants. Critical Reviews in Plant Sciences 24:23-58. doi:10.1080/07352680590910410.

Bouizgaren, A. 2007. Technical sheet for alfalfa growing in Morocco: Techniques of forage and seed production. 27 p. INRA Publishing, Marrakesh, Morocco.

Bouizgaren, A., M. Farissi, C. Ghoulam, R. Kallida, M. Faghire, M. Barakate, et al. 2013. Assessment of summer drought tolerance variability in Mediterranean alfalfa (Medicago sativa L.) cultivars under Moroccan fields conditions. Archives of Agronomy and Soil Science 59(1):147-160. doi:10.1080/03650 340.2011.606216.

Bradford, K.J. 1986. Manipulation of seed water relations via osmotic priming to improve germination under stress conditions. Horticultural Science 21:1105-1112.

Table 4. Pearson correlations between the studied parameters. Values represent correlation coefficients.

\begin{tabular}{|c|c|c|c|c|c|c|c|c|c|c|c|}
\hline & FGP & GR & MGT & T50 & SL & RL & $\mathrm{S} / \mathrm{R}$ & MDA & PO & CAT & EL \\
\hline FGP & 1 & $0.258^{* *}$ & $-0.213^{*}$ & $-0.171^{\mathrm{NS}}$ & $0.789^{* *}$ & $0.854^{* *}$ & $-0.011^{\mathrm{NS}}$ & $-0.824^{* *}$ & $0.415^{* *}$ & $0.161 *$ & $-0.811^{* *}$ \\
\hline GR & & 1 & $-0.792^{* *}$ & $-0.787^{* *}$ & $0.148^{\mathrm{NS}}$ & $0.198^{*}$ & $0.242^{*}$ & $-0.271^{* *}$ & $-0.026^{\mathrm{NS}}$ & $0.09^{\mathrm{NS}}$ & $-0.135^{\mathrm{NS}}$ \\
\hline MGT & & & 1 & $0.549^{* *}$ & $-0.105^{\mathrm{NS}}$ & $-0.13^{\mathrm{NS}}$ & $-0.177^{\mathrm{NS}}$ & $0.213^{*}$ & $-0.055^{\mathrm{NS}}$ & $-0.099^{\mathrm{NS}}$ & $0.099^{\mathrm{NS}}$ \\
\hline T50 & & & & 1 & $-0.126^{\mathrm{NS}}$ & $-0.176^{\mathrm{NS}}$ & $-0.229^{*}$ & $0.234 *$ & $0.061^{\mathrm{NS}}$ & $0.031^{\mathrm{NS}}$ & $0.049^{\mathrm{NS}}$ \\
\hline Shoot L & & & & & 1 & $0.954^{* *}$ & $-0.362^{* *}$ & $-0.880^{* *}$ & $-0.567^{* *}$ & $-0.373 * *$ & $-0.915^{* *}$ \\
\hline Root L & & & & & & 1 & $-0.107^{\mathrm{NS}}$ & $-0.888^{* *}$ & $-0.514^{* *}$ & $-0.299 * *$ & $-0.916^{* *}$ \\
\hline $\mathrm{S} / \mathrm{R}$ ratio & & & & & & & 1 & $0.168^{\mathrm{NS}}$ & $0.198 *$ & $0.194 *$ & $0.259^{* *}$ \\
\hline MDA & & & & & & & & 1 & $-0.507^{* * *}$ & $-0.748^{* * * *}$ & $0.827^{* *}$ \\
\hline $\mathrm{PO}$ & & & & & & & & & 1 & $0.907^{* *}$ & $-0.777^{* * * *}$ \\
\hline CAT & & & & & & & & & & 1 & $-0.698^{* * *}$ \\
\hline EL & & & & & & & & & & & 1 \\
\hline
\end{tabular}

${ }^{*},{ }^{* *},{ }^{* * *}$ Significant at the $0.05,0.01$, and 0.001 probability levels, respectively; NS: nonsignificant at 0.05 probability level.

FGP: Final germination percentage, GR: germination rate, MGT: mean germination time, T50: time to 50\% germination, SL: shoot length, RL: root length, S/R: shoot to root ratio, MDA: malonyldialdehyde, PO: peroxidase, CAT: catalase, EL: electrolyte leakage. 
Butler, L.H., F.R. Hay, R.H. Ellis, R.D. Smith, and T.B. Murray. 2009. Priming and re-drying improve the survival of mature seeds of Digitalis purpurea during storage. Annals of Botany 103:1261-1270. doi:10.1093/aob/mcp059.

Chen, K., and R. Arora. 2011. Dynamics of the antioxidant system during seed osmopriming, post-priming germination, and seedling establishment in spinach (Spinacia oleracea). Plant Science 180:212-220. doi:10.1016/j.plantsci.2010.08.007.

Conrath, U. 2011. Molecular aspects of defense priming. Trends in Plant Science 16(10):524-531.doi:10.1016/j.tplants.2011.06.004.

Coolbear, P., A. Francis, and D. Grierson. 1984. The effect of low temperature pre-sowing treatment under the germination performance and membrane integrity of artificially aged tomato seeds. Journal of Experimental Botany 35:1609-1617. doi:10.1093/jxb/35.11.1609.

Cruz de Carvalho, M.H. 2008. Drought stress and reactive oxygen species. Plant Signaling and Behavior 3:156-165.

Farissi, M., A. Bouizgaren, M. Faghire, A. Bargaz, and C. Ghoulam. 2011. Agro-physiological responses of Moroccan alfalfa (Medicago sativa L.) populations to salt stress during germination and early seedling stages. Seed Science and Technology 39:389401. doi:http://dx.doi.org/10.15258/sst.2011.39.2.11.

Farooq, M., S.M.A. Basra, K. Hafeez, and N. Ahmad. 2005. Thermal hardening: A new seed vigor enhancement tool in rice. Journal of Integrative Plant Biology 47:187-193. doi:10.1111/ j.1744-7909.2005.00031.x.

Figueiredo e Albuquerque, M.C. de, and N.M. de Carvalho. 2003. Effect of the type of environmental stress on the emergence of sunflower (Helianthus annuus L.), soybean (Glycine max (L.) Merril) and maize (Zea mays L.) seeds with different levels of vigor. Seed Science and Technology 31:465-469. doi:http:// dx.doi.org/10.15258/sst.2003.31.2.23.

Foyer,C.H., and G.Noctor. 2005. Redox homeostasis and antioxidant signaling: a metabolic interface between stress perception and physiological responses. The Plant Cell 17(7):1866-1875. http:// dx.doi.org/10.1105/tpc.105.033589.

França, M.B., A.D. Panek, and E.C.A. Eleutherio. 2007. Oxidative stress and its effects during dehydration. Comparative Biochemistry and Physiology Part A: Molecular \& Integrative Physiology 146(4):621-631. doi:10.1016/j.cbpa.2006.02.030.

Gao, J.F. (ed.) 2000. Experimental technology in plant physiology. p. 101-103. World Map and Book Press, Xi'an, China.

Ghassemi-Golezani, K., B. Dalil, A.D. Muhammadi-Nasab, and S. Zehtab-Salmasi. 2008. The response of Chickpea cultivars to field water deficit. Notulae Botanicae Horti Agrobotanici ClujNapoca 36:25

Ghoulam, C., A. Foursy, and K. Fares. 2002. Effects of salt stress on growth, inorganic ions and proline accumulation in relation to osmotic adjustment in five sugar beet cultivars. Environmental and Experimental Botany 47:39-50. doi:10.1016/S00988472(01)00109-5.

Halmer, P. 2004. Methods to improve seed performance in the field. Handbook of Seed Physiology, Applications to Agriculture 125-165.

Hamidi, H., and A. Safarnejad. 2010. Effect of drought stress on alfalfa cultivars (Medicago sativa L.) in germination stage. American-Eurasian Journal of Agricultural \& Environmental Sciences 8(6):705-709.

Harb, E.Z. 1992. Effect of soaking seeds in some growth regulators and micronutrients on growth, some chemical constituents and yield of faba bean and cotton plants. Bulletin of Faculty of Agriculture, Cairo University 43:429-452.
Hasanuzzaman, M., K. Nahar, M.M. Alam, R. Roychowdhury, and M. Fujita. 2013. Physiological, biochemical, and molecular mechanisms of heat stress tolerance in plants. International Journal of Molecular Sciences 14(5):9643-9684. http://doi. org/10.3390/ijms14059643.

Jisha, K.C., K. Vijayakumari, and J.T. Puthur. 2013. Seed priming for abiotic stress tolerance: an overview. Acta Physiologiae Plantarum 35(5):1381-1396. doi:10.1007/s11738-012-1186-5.

Kibinza, S., J. Bazin, C. Bailly, J.M. Farrant, F. Corbineau, and H. El-Maarouf Bouteau. 2011. Catalase is a key enzyme in seed recovery from ageing during priming. Plant Science 181(3):309315. doi:10.1016/j.plantsci.2011.06.003.

Latrach, L., M. Farissi, M. Mouradi, B. Makoudi, A. Bouizgaren, and C. Ghoulam. 2014. Growth and nodulation of alfalfarhizobia symbiosis under salinity: electrolyte leakage, stomatal conductance, and chlorophyll fluorescence. Turkish Journal of Agriculture and Forestry 38:320-326. doi:10.3906/tar-1305-52.

Michel, B.E., and M.R. Kaufmann. 1973. The osmotic potential of polyethylene glycol 6000. Plant Physiology and Biochemistry 51(5):914-917. http://dx.doi.org/10.1104/pp.51.5.914.

Mittler, R. 2002. Oxidative stress, antioxidants and stress tolerance. Trends in Plant Science 7(9):405-410.

Moradi Dezfuli, P., F. Sharif-zadeh, and M. Janmohammadi. 2008. Influence of priming techniques on seed germination behavior of maize inbred lines (Zea mays L.) ARPN Journal of Agricultural and Biological Science 3(3):22-25

Mouradi, M., M. Farissi, A. Bouizgaren, B. Makoudi, A. Kabbadj, A.A. Very, et al. 2016. Effects of water deficit on growth, nodulation and physiological and biochemical processes in Medicago sativa-rhizobia symbiotic association. Arid Land Research and Management 30(2):193-208. doi:10.1080/153249 82.2015.1073194.

Rahimi, A. 2013. Seed priming improves the germination performance of cumin (Cuminum syminum L.) under temperature and water stress. Industrial Crops and Products 42:454-460. doi:10.1016/j.indcrop.2012.06.026.

Sadeghi, H., F. Khazaei, L. Yari, and S. Sheidaei. 2011. Effect of seed osmopriming on seed germination behavior and vigor of soybean (Glycine max L.) ARPN Journal of Agricultural and Biological Science 6(1):39-43.

Sharma, P., A.B. Jha, R.S. Dubey, and M. Pessarakli. 2012. Reactive oxygen species, oxidative damage, and antioxidative defense mechanism in plants under stressful conditions. Journal of Botany http://dx.doi.org/10.1155/2012/217037.

Sun, Y.Y., Y.J. Sun, M.T. Wang, X.Y. Li, X. Guo, R. Hu, et al. 2010. Effects of seed priming on germination and seedling growth under water stress in rice. Acta Agronomica Sinica 36(11):19311940. doi:10.1016/S1875-2780(09)60085-7.

Wang, W.B., Y.H. Kim, H.S. Lee, K.Y. Kim, X.P. Deng, and S.S. Kwak. 2009. Analysis of antioxidant enzyme activity during germination of alfalfa under salt and drought stresses. Plant Physiology and Biochemistry 4:570-577. doi:10.1016/j. plaphy.2009.02.009.

Yacoubi, R., C. Job, M. Belghazi, W. Chaibi, and D. Job. 2013. Proteomic analysis of the enhancement of seed vigour in osmoprimed alfalfa seeds germinated under salinity stress. Seed Science Research 23:99-110. http://dx.doi.org/10.1017/ S0960258513000093.

Zhang, J.X., and M.B. Kirham. 1994. Drought stress-induced changes in activities of superoxide dismutase, catalase, and peroxidase in wheat species. Plant and Cell Physiology 35:785-791. 